\title{
PENGARUH LINGKUNGAN FISIK DAN PELAYANAN TERHADAP KEPUASAN PASIEN UPT PUSKESMAS CIPUTAT TIMUR KOTA TANGERANG SELATAN
}

\author{
${ }^{1}$ Azizah Setyawati \\ ${ }^{2}$ Rissa Hanny \\ Program Studi Manajemen, Fakultas Ekonomi, Universitas Pamulang \\ Email: zachrie27@gmail.com ${ }^{1}$, rissa.hanny@gmail.com ${ }^{2}$
}

\begin{abstract}
ABSTRAK
Tujuan penelitian ini untuk mengetahui adanya pengaruh yang ditimbulkan dari variabel lingkungan fisik dan pelayanan terhadap kepuasan pasien pada UPT. Puskesmas Ciputat Timur, Kota Tangerang Selatan. Kepuasan pasien merupakan salah satu indikator di dalam menentukan berhasil tidaknya suatu organisasi maupun perusahaan dalam meraih tujuan yang telah ditetapkan. Jenis penelitian menggunakan riset survei. Subjek penelitian ini melibatkan 50 orang pasien Puskesmas. Teknik pengumpulan data menggunakan perangkat kuesioner, observasi dan teknik studi kepustakaan, sedangkan teknik análisis data menggunakan análisis deskriptif kuantitatif dan statistik inferensial melalui pengujian validitas dan reliabilitas data, uji asumsi klasik, dan pengujian hipotesis penelitian dengan bantuan Software SPSS Versi 23.00. Hasil dari penelitian ini antara lain: (1) Lingkungan Fisik dan Pelayanan berpengaruh signifikan secara simultan terhadap Kepuasan Pasien; dan (2) Lingkungan Fisik terhadap kepuasan pasien tidak berpengaruh signifikan sementara Pelayanan terhadap kepuasan pasien berpengaruh signifikan, artinya semakin baik pelayanan pasien pada UPT Puskesmas Ciputat Timur akan semakin meningkat kepuasan pasien.
\end{abstract}

Kata kunci: kepuasan pasien, lingkungan fisik, pelayanan.

\begin{abstract}
The purpose of this research was to determine the effect caused by physical environment and services variables to the patient satisfaction at UPT. Puskesmas Ciputat Timur, South Tangerang City. Patient satisfaction is one indicator of determining the successing an organization although company in achieving the goals. This type of study uses survey research. The subjects of this study involved 50 patients from the Puskesmas. Data collection techniques using questionnaires, observation and literature study techniques, while the data analysis technique uses quantitative descriptive analysis and inferential statistics through the data validity and reliability testing, classic assumptions tests, and hypothesis test with the support of SPSS Software Version 23.00. The results of this study include: (1) Physical Environment and Services have a significant effect simultaneously to the Patient Satisfaction; and (2) Physical Environment to the patient satisfaction doesn't have a significant effect while Service to the patient satisfaction has a significant effect, meaning that patient service is the better at the UPT Puskesmas Ciputar Timur will increasingly increase patient satisfaction.
\end{abstract}

Keywords: patient satisfaction, physical environment, services. 


\section{PENDAHULUAN}

Seseorang akan merasa memiliki kondisi fisik dan mental yang baik jika terbebas dari berbagai penyakit. Selain itu, kehidupan manusia juga tidak terlepas dari kondisi atau lingkungan sosial. Suatu keadaan normal manusia dengan kriteria dan standar berdasarkan jenis kelamin dan komunitas masyarakat sekitar yang diterima mencerminkan konsep sehat (Finansial.com, 2019). Sehat itu mahal yang selalu dikatakan oleh banyak orang, akan tetapi fakta ini apakah benar. Menurut pendapat para Ilmu Kesehatan Dunia (WHO), kita harus mengkonsumsi makanan yang kayak akan gizi, seperti protein, zat besi, dan lainnya sehingga sehat dapat dikatakan mahal (Aritonang, H., Erdiansih, \& Ningsih, 2016). Di Indonesia sendiri, kesehatan masyarakat pada saat ini dapat dinyatakan dalam kondisi yang semakin membaik, meskipun masih terdapat sebagian masyarakat yang memiliki pola hidup yang jauh dari kata sehat. Aktivitas masyarakat yang terorganisir pada lingkungan hidup meliputi kontrol infeksi, peningkatan sistem sanitasi, layanan perawatan dan medis, pencegahan penyakit dan pengembangan aspek-aspek sosial di masyarakat akan mendukung standar kehidupan seseourang agar masyarakat mempunyai peranan yang kuat untuk turut menjaga kesehatannya (Nico A. Lumenta, 2006, hal. XV).

Puskesmas adalah unit pelaksana teknis Dinas Kesehatan Kabupaten/Kota yang bertanggungjawab dalam penyelenggaraan pembangunan kesehatan di satu atau sebagian wilayah kerja. Puskesmas sebagai pelayanan kesehatan pada strata pertama yang meliputi pelayanan kesehatan perorangan, masyarakat dan kegiatan yang diselenggarakan oleh puskesmas. Selain itu, peran serta masyarakat diperlukan dalam rangka mengembangkan kesehatan terutama di lingkungan masyarakat intern yang sangat mendasar sehingga pelayanan kesehatan dapat lebih dikembangkan (Keputusan Menteri Kesehatan RI, 2014, hal. 5-6).

Puskesmas melaksanakan kegiatan pokok yang diarahkan kepada keluarga sebagai satuan masyarakat terkecil untuk kepentingan sebagai bagian dari masyarakat di wilayah kerjanya yang dilaksanakan dengan pendekatan Pembangunan Kesehatan Masyarakat Desa (PKMD) (Effendi \& Makhfudli, 2009, hal. 280). Puskesmas dapat diminta sewaktu-waktu dalam rangka melaksanakan program kesehatan tertentu oleh Pemerintah Pusat, seperti PIN (Pekan Imunisasi Nasional). Petunjuk pelaksanaan dan perbekalan yang diberikan oleh Pemerintah Pusat dan Pemerintah Daerah dan dalam hal lainnya seperti keadaan darurat mengenai kesehatan, misalnya timbulnya wabah penyakit menular atau karena bencana alam. Kejadian darurat tersebut dapat diatasiu dengan mengurangi atau menunda kegiatan lain. Puskesmas menjadi ujung tombak bagi pelayanan kesehatan masyarakat yang cukup efektif dalam 
membantu dan memberikan pertolongan pertama masyarakat dengan standar pelayanan kesehatan sebagai pelayanan kesehatan yang dikenal murah oleh masyakarat. Puskesmas seharusnya menjadi pelayanan kesehatan yang utama, namun pada kenyataannya masyarakat sebagian besar lebih cenderung memilih dokter praktek swasta atau dokter praktek lainnya (Sanah, 2017). Pelayanan puskesmas menjadi salah satu tolok ukur internal bagaimana pelayanan lingkungan kerja yang ada di suatu instansi akan berjalan dengan baik yang akan berpengaruh terhadap kinerja karyawan. Lingkungan kerja yang menyenangkan bagi karyawan melalui pengikatan hubungan yang harmonis dengan atasan, rekan kerja maupun bawahan serta didukung oleh sarana dan prasarana yang memadai yang terdapat ditempat kerjaakan membawa dampak yang positif bagi karyawan.

Lingkungan kerja fisik adalah semua keadaan berbentuk fisik yang terdapat di sekitar tempat kerja yang dapat mempengaruhi pegawai baik secara langsung maupun secara tidak langsung (Sedarmayanti, 2018, hal. 26) sementara semua keadaan yang terjadi berkaitan dengan hubungan kerja, baik hubungan dengan atasan maupun dengan rekan kerja, ataupun hubungan dengan bawahan (Sedarmayanti, 2018, hal. 32) atau bahkan hubungan dengan pasien sekalipun.

Penelitian ini bertujuan untuk menguji secara empiris lingkungan fisik dan pelayanan yang menjadi ujung tombak kesehatan masyarakat terhadap kepuasan pasien. Subjek penelitian ini adalah pasien di UPT Puskesmas Ciputat Timur, Kota Tangerang Selatan.

Manajemen dikatakan sebagai ilmu karena manajemen dapat dipelajari dan dikaji kebenarannya (Handoko, 2015, hal. 8). Pentingnya pengaturan Manajemen Sumber Daya Manusia (MSDM) di lingkungan pelayanan kesehatan yang dilakukan melalui serangkaian proses yang diatur berdasarkan urutan dari fungsi-fungsi manajemen atau dikenal dengan istilah to manage yang berarti mengatur, mengurus atau mengelola (Hasibuan, 2017).

Lingkungan kerja merupakan kumpulan dari faktor yang bersifat fisik maupun non fisik. Dimensi untuk mengukur lingkungan kerja fisik menggunakan indikator, yaitu (1) lingkungan kerja yang secara langsung berhubungan dengan karyawan dengan indikator yang meliputi pusat kerja, meja, kursi dan sebagainya; serta (2) lingkungan kerja yang mempengaruhi kondisi manusia dengan indikator yang meliputi penerangan / pencahayaan, sirkulasi udara, tata warna, musik, kebersihan, dan keamanan (Sedarmayanti, 2018, hal. 21). Pengaruh lingkungan fisik terhadap karyawan dapat diperkecil dengan mempelajari karakter dan tingkah laku manusia sebagai dasar untuk memikirkan lingkungan fisik yang sesuai 
dengan lingkungannya. Pelayanan merupakan kegiatan atau setiap tindakan yang dapat ditawarkan oleh satu pihak kepada pihak lainnya secara tidak berwujud yang tidak mengakibatkan kepemilikan apapun (Kotler, Philip T., Keller, Kevin Lane, 2014). Pelayanan adalah serangkaian kegiatan dengan menggunakan kualitas atas produk yang bergantung kepada upaya atau cara dalam keinginan dan permintaan pelanggan (Husain \& Sani, 2020). Oleh karena itu, pelayanan merupakan sebuah proses yang berlangsung secara berkesinambungan dan mencakup rutinitas seluruh kehidupan masyarakat.

Kepuasan dapat didefinisikan sebagai upaya pemenuhan sesuatu atau membuat sesuatu memadai (Tjiptono, 2014). Kepuasan pasien merupakan evaluasi atau penilaian setelah memakai suatu pelayanan, bahwa pelayanan yang dipilih setidak-tidaknya memenuhi atau melebihi harapan (Mamik, 2010; Az-zahroh, 2017). Perasaan individu atas senang dan puas karena harapan dan kenyataan dalam suatu layanan yang diberikan akan terpenuhi.

Penelitian ini dilatarbelakangi oleh reviu peneliti terdahulu antara lain: (1) Pengaruh Mutu Pelayanan Kesehatan terhadap Tingkat Kepuasan Pasien Rawat Inap di Ruang Dewasa Umum Rumah Sakit X Kabupaten Gresik yang melibatkan 117 pasien dengan metode analisis regresi linier sederhana. Temuan penelitian membuktikan bahwa mutu pelayanan kesehatan mempunyai pengaruh signifikan terhadap kepuasan pasien (Az-zahroh, 2017); (2) Pelaksanaan Fungsi Puskesmas (Pusat Kesehatan Masyarakat) Ddalam Meningkatkan Kualitas Pelayanan Kesehatan dengan pendekatan penelitian kepustakaan dan studi lapangan. Teknik analisa data menggunakan analisis interaktif yang merupakan rangkaian dari proses pengumpulan data, penyajian dan reduksi data dan penarikan kesimpulan. Hasil penelitian menjelaskan pelaksanaan fungsi Puskesmas sebagai pelayanan kesehatan sudah cukup baik dalam meningkatkan kualitas melalui serangkaian prosedur pelayanan pasien yang cukup mudah yang datang dalam konteks pemeriksaan maupun pengobatan (Sanah, 2017); dan (3) Pengaruh Lingkungan Kerja Terhadap Kepuasan Kerja Karyawan yang melibatkan 63 karyawan PT. Mitra Pinasthika Mustika Rent Tangerang Selatan dengan analisis statistik deskriptif dan analisis inferensial. Temuan penelitian mengkonfirmasikan bahwa secara simultan dan parsial Lingkungan Kerja Fisik dan Non-Fisik berpengaruh signifikan terhadap Kepuasan Kerja Karyawan (Sitinjak, 2018). Dengan demikian, dapat dirumuskan secara spesifik rerangka model penelitian berikut ini: 


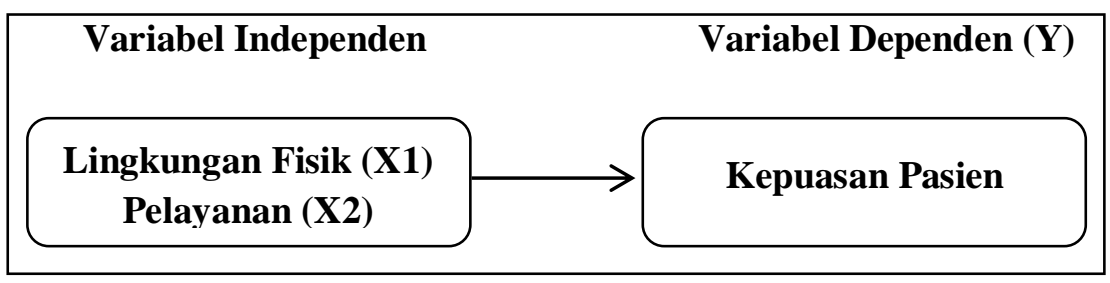

Gambar 1 Rerangka Model Penelitian

Hipotesis penelitian ini dirumuskan sebagai berikut:

$\mathrm{H}_{1}$, diduga lingkungan fisik berpengaruh signifikan terhadap kepuasan pasien

$\mathrm{H}_{2}$, diduga pelayanan berpengaruh signifikan terhadap kepuasan pasien

\section{METODE PENELITIAN}

Penelitian ini merupakan jenis kausalitas, yaitu tipe penelitian dengan karakteristik masalah berupa hubungan yang bersifat sebab akibat antara variabel independen (variabel yang mempengaruhi) dan dependen (dipengaruhi) (Sugiyono, 2018, hal. 62). Penelitian ini menggunakan pendekatan kuantitatif dimana merupakan serangkaian observasi atau pengukuran hasilnya menggunakan data primer berupa survei kepada responden. Penelitian dilakukan di UPT Puskesmas Ciputat Timur, Kota Tangerang Selatan selama periode Maret sampai dengan Mei tahun 2019. Pertimbangan ini atas berbagai faktor dalam pengumpulan data penelitian seperti proses dalam pengambilan data, penggunaan dana yang tidak terlalu besar serta penghematan waktu dan tenaga yang dipergunakan sehingga memerlukan periode waktu yang cukup panjang. Populasi adalah wilayah yang digeneralisasi atas subyek atau obyek yang mempunyai kualitas dan karakteristik tertentu yang ditetapkan oleh peneliti untuk dipelajari dan kemudian ditarik kesimpulannya (Sugiyono, 2018, hal. 117). Sampel adalah bagian dari karakteristik dan jumlah yang dimiliki oleh populasi (Sugiyono, 2018, hal. 118). Populasi yang menjadi subjek pada penelitian ini adalah pasien pada UPT Puskesmas dengan teknik convenience sampling dikarenakan keterbatasan waktu dan tenaga sehingga ditetapkan sebanyak 50 (lima puluh) orang. Sumber data penelitian ini meliputi data primer yaitu data yang diperoleh kuesioner pada pasien UPT Puskesmas Ciputat Timur pada tahun 2019. Teknik analisis data menggunakan program SPSS for Windows Ver.23 melalui tahapan berikut ini: (1) Analisis deskriptif berdasarkan kriteria jawaban responden; (2) Uji validitas menggunakan rumus product moment dengan ketentuan jika $\mathrm{r}_{\text {hitung }}>\mathrm{r}$ tabel maka instrumen valid dan uji reliabilitas menggunakan rumus coefficient alpha cronbach's dengan ketentuan minimal 0,6 maka instrumen reliabel (Sugiyono, 2018); (3) Analisis Regresi menggunakan pendekatan linier berganda $Y=a+b_{1} X_{1}+b_{2} X_{2}+\ldots . . b_{n} X_{n}$; dan (4) Uji hipotesis melalui 
analisis koefisien korelasi dan koefisien determinasi menggunakan nilai $R$-Square dengan ketentuan Ho ditolak dan Ha diterima jika $\mathrm{t}$ hitung $>\mathrm{t}$ tabel (uji parsial) dan $\mathrm{F}$ hitung $>\mathrm{F}$ tabel (uji simultan)

\section{HASIL PENELITIAN DAN PEMBAHASAN}

\section{Hasil Penelitian}

Deskriptif statistik yang digambarkan pada penelitian ini meliputi lingkungan kerja fisik, pelayanan, dan kepuasan pasien pada UPT Puskesmas Ciputat Timur.

Tabel 1 Statistik Deskriptif

\begin{tabular}{lrrrrr}
\hline & N & Minimum & Maximum & Mean & Std. Deviation \\
\hline Lingkungan Fisik & 50 & 34,00 & 50,00 & 41,2200 & 3,49513 \\
\hline Pelayanan & 50 & 30,00 & 50,00 & 39,2600 & 4,44380 \\
\hline Kepuasan Pasien & 50 & 30,00 & 47,00 & 39,6000 & 3,96927 \\
\hline Valid N (listwise) & 50 & & & & \\
\hline
\end{tabular}

Tabel 1 menjelaskan variabel lingkungan fisik mendapakan nilai jawaban minimum 34,00. dan nilai jawaban maksimum 50,00. dengan jawaban rata-rata 41,22. dan standar deviasi sebesar 3,49. Pada variabel pelayanan mempunyai nilai minimum 30,00. dan nilai maksimum 50,00. sedangkan nilai rata-rata nya adalah 39,26.dan standar deviasi sebesar 4,26. Variabel kepuasan pasien mempunyai nilai minimum 30,00. dan nilai jawaban maksimum 47,00. dengan jawaban rata-rata 39,60.dan standar deviasi sebesar 3,96.

Uji validitas dan reliabilitas digunakan untuk mengukur sah atau valid tidaknya suatu data kuesioner serta dapat dihandalkan apa tidaknya suatu instrumen (variabel) penelitian. Butir pernyataan kuesioner dikatakan valid apabila penyataan kuesioner mampu mengungkapkan yang diukur oleh kuesioner tersebut. Uji validitas dilakukan dengan menggunakan pearson moment corelation pada dilakukan dengan membandingkan nilai r-hitung dengan r-tabel, suatu indikator dikatakan valid apabila r-hitung > r-tabel (r-tabel sebesar 0,2787, $\mathrm{dF}=48$ (Ghozali, 2017, hal. 463).

Tabel 2 Rangkuman Hasil Uji Validitas dan Reliabilitas

\begin{tabular}{lclc}
\hline Indikator & r-hitung & $\begin{array}{c}\text { Hasil Uji } \\
\text { Validitas }\end{array}$ & $\begin{array}{c}\text { Nilai Cronbach's } \\
\text { Alpha / Kesimpulan } \\
\text { Uji Reliabilitas }\end{array}$ \\
\hline \multicolumn{2}{l}{ Variabel Lingkungan Fisik (X1) } & \\
\hline LF1 & $0,460^{* *}$ & valid & \\
LF2 & $0,546^{* *}$ & valid & $0,719>0,6$, Reliabel \\
LF3 & $0,642^{* *}$ & valid & \\
LF4 & $0,592^{* *}$ & valid & \\
\hline
\end{tabular}




\begin{tabular}{lcll}
\hline Indikator & r-hitung & $\begin{array}{c}\text { Hasil Uji } \\
\text { Validitas }\end{array}$ & $\begin{array}{c}\text { Nilai Cronbach's } \\
\text { Alpha / Kesimpulan } \\
\text { Uji Reliabilitas }\end{array}$ \\
\hline LF5 & $0,566^{* *}$ & valid & \\
LF6 & $0,430^{* *}$ & valid & \\
LF7 & $0,552^{* *}$ & valid & \\
LF8 & $0,366^{* *}$ & valid & \\
LF9 & $0,603^{* *}$ & valid & \\
LF10 & $0,568^{* *}$ & valid & \\
\hline Variabel Pelayanan $(\mathrm{X} 2)$ & & \\
\hline PEL1 & $0,495^{* *}$ & valid & \\
PEL2 & $0,521^{* *}$ & valid & \\
PEL3 & $0,586^{* *}$ & valid & \\
PEL4 & $0,618^{* *}$ & valid & \\
PEL5 & $0,632^{* *}$ & valid & \\
PEL6 & $0,495^{* *}$ & valid & \\
PEL7 & $0,680^{* *}$ & valid & \\
PEL8 & $0,512^{* *}$ & valiabel \\
PEL9 & $0,608^{* *}$ & valid & \\
PEL10 & $0,662^{* *}$ & valid & \\
\hline Variabel Kepuasan Pasien $(Y)$ & & \\
\hline KP1 & $0,495^{* *}$ & valid & \\
KP2 & $0,521^{* *}$ & valid & \\
KP3 & $0,586^{* *}$ & valid & \\
KP4 & $0,618^{* *}$ & valid & \\
KP5 & $0,632^{* *}$ & valid & \\
KP6 & $0,495^{* *}$ & valid & \\
KP7 & $0,680^{* *}$ & valid & \\
KP8 & $0,512^{* *}$ & valid & \\
KP9 & $0,608^{* *}$ & valid & \\
KP10 & $0,662^{* *}$ & valid & \\
\hline
\end{tabular}

Keseluruhan butir pernyataan dan instrumen X1, X2 dan Y memiliki skor r-hitung lebih besar (>) dari 0,2787 pada sampel 50 responden. Di samping itu, semua item dalam variabel yang diteliti memiliki nilai cronbach's alpha lebih besar (>) dari 0,60 sehingga disimpulkan bahwa semua butir-butir pernyataan yang terdapat dalam kuesioner adalah valid dan instrumen memiliki reliabilitas yang layak digunakan sebagai instrumen penelitian.

Tabel 3 Rangkuman Hasil Uji Kolmogorov Smirnov

\begin{tabular}{lccc}
\hline & $\begin{array}{c}\text { Lingkungan } \\
\text { Fisik }\end{array}$ & Pelayanan & $\begin{array}{c}\text { Kepuasan } \\
\text { Pasien }\end{array}$ \\
\hline Kolmogorov-Smirnov Z & 0,824 & 0,522 & 0,691 \\
\hline Asymp. Sig. (2-tailed) & 0,506 & 0,948 & 0,725 \\
\hline
\end{tabular}

Hasil uji One-Sample Kolmogorov-Smirnov (K/S) memperlihatkan besarnya nilai Kolmogorov-Smirnov Z masing-masing variabel penelitian adalah 0,824, 0,522 dan 0,691 serta memiliki nilai Asymp. Sig (2-tailed) masing-masing lebih besar dari 0,05 yaitu 0,506, 
0,948 dan 0,725 . Hasil pengujian ini tidak signifikan padal level $\alpha 5 \%$ sehingga $\mathrm{H}_{0}$ diterima. Hasil pengujian ini telah memenuhi asumsi uji normalitas.

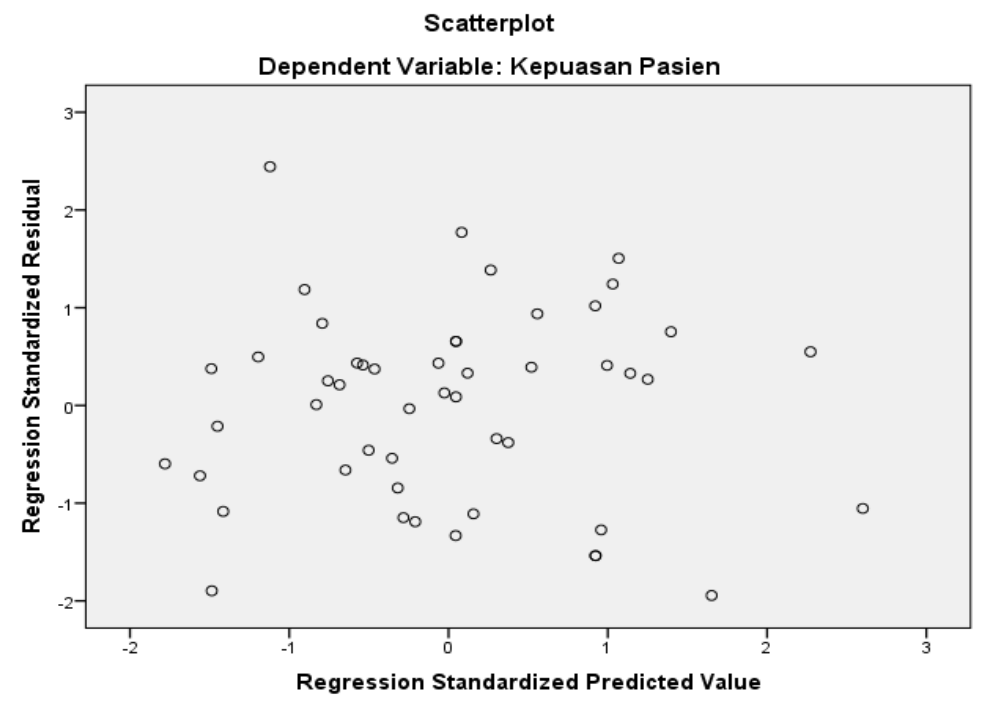

Gambar 2 Grafik Scatterplot

Grafik scatterplot dari variabel Kepuasan Pasien menghasilkan sebaran titik-titik menyebar di bawah dan di atas angka 0 (nol) pada sumbu Y. Hasil pengujian ini berarti model penelitian ini terbebas dari masalah heteroskedastisitas antar variabel.

Tabel 4 Rangkuman Hasil Uji Multikolinearitas

\begin{tabular}{lcc}
\hline & Nilai Tolerance & Nilai VIF \\
\hline Lingkungan Fisik (X1) & 0,552 & 1,810 \\
\hline Pelayanan (X2) & 0,552 & 1,810 \\
\hline
\end{tabular}

Nilai tolerance pada variabel X1 dan X2 lebih besar (>) daripada 0,1 dan nilai VIF lebih kecil $(<)$ daripada 10 yang berarti model regresi tidak memiliki gejala multikolonieritas antar variabel independen.

Tabel 5 Rangkuman Hasil Uji Koefisien Korelasi (R) dan Determinasi ( $\left.\mathrm{R}^{2}\right)$

\begin{tabular}{lcccc}
\hline Model & $\mathbf{R}$ & $\mathbf{R}^{\mathbf{2}}$ & Adjusted $\mathbf{R}^{\mathbf{2}}$ & SE of the Estimate \\
\hline 1 & $0,495^{\mathrm{a}}$ & 0,245 & 0,213 & 3,52124 \\
\hline
\end{tabular}

Nilai koefisien korelasi (R) sebesar 0,495 dinyatakan bahwa hubungan antara variabel X (Lingkungan Fisik dan Pelayanan) terhadap variabel Y (Kepuasan Pasien) berada pada interval 0,400 - 0,599, hal ini menunjukkan bahwa korelasi berganda antara variabel kedua variabel di atas menunjukkan hubungan yang cukup kuat. Nilai koefisien determinasi $\left(\mathrm{R}^{2}\right)$ diperoleh sebesar 0,245 yang berarti 24,5 persen perubahan dari variabel Lingkungan Fisik 
dan Pelayanan (X1;X2) dijelaskan oleh variasi variabel Kepuasan Pasien (Y), sedangkan sisanya 75,5 persen dijelaskan oleh variabel lain yang tidak diikutsertakan pada penelitian ini.

Tabel 6 Rangkuman Hasil Uji ANOVA

\begin{tabular}{lccc}
\hline Model & df & F & Sig. \\
\hline 1 & 2 & 7,631 & $0,001^{\mathrm{b}}$ \\
\hline
\end{tabular}

Nilai F-hitung diketahui sebesar 7,631 dengan probabilitas signifikansi yang lebih kecil $(<)$ dari alpha 5\%, yaitu 0,001 , sehingga menolak $\mathrm{H}_{0}$. Variabel Lingkungan Fisik (X1) dan Pelayanan (X2) secara simultan berpengaruh signifikan terhadap variabel Kepuasan Pasien (Y).

Hasil dari uji parsial dituangkan dengan hasil persamaan regresi berganda sebagai berikut:

$\mathrm{Y}=19,610+0,143 \mathrm{X} 1+0,359 \mathrm{X} 2+\mathrm{è}$

Constant : 19,+610. Artinya rata-rata kontribusi variabel independen selain X1 dan X2 juga memberikan dampak positif terhadap nilai Y.

$\mathrm{X} 1 \quad$ : 0,143. Artinya X1 memiliki pengaruh positif terhadap $\mathrm{Y}$, jika terjadi kenaikan X1 sebesar 1 (satu) kali dan variabel independen lainnya bernilai tetap, maka Y akan mengalami peningkatan sebesar 1 .

X2 : 0,359. Artinya X2 memiliki pengaruh positif terhadap Y, jika terjadi kenaikan X2 sebesar 1 (satu) kali dan variabel independen lainnya bernilai tetap, maka Y akan mengalami peningkatan sebesar 1 .

Pengaruh lingkungan fisik terhadap kepuasan pasien menghasilkan probabilitas signifikansi sebesar 0,464 > 0,05 yang artinya lingkungan fisik pada UPT Puskesmas Ciputat Timur, Kota Tangerang Selatan tidak signifikan terhadap Kepuasan Pasien. Hasil pengujian hipotesis ini tidak sejalan dengan temuan atas baik secara simultan dan parsial Lingkungan Fisik dan Non-Fisik berpengaruh signifikan terhadap Kepuasan Kerja (Sitinjak, 2018). Pentingnya lingkungan fisik yang tidak terlepas dari serangkaian kegiatan yang menentukan kualitas atas produk yang secara rutin harus dijaga berkesinambungan yang berfungsi untuk mencapai kepuasan pasien secara optimal sebagaimana diamanatkan dalam UUD 1945 Pasal $28 \mathrm{H}$ ayat (1) untuk mendapat lingkungan hidup yang baik dan sehat, serta berhak memperoleh pelayanan kesehatan (Sanah, 2017; Husain \& Sani, 2020). Pelayanan terhadap kepuasan pasien menghasilkan probabilitas signifikansi sebesar 0,023 $<0,05$ yang artinya pelayanan pada UPT Puskesmas Kecamatan Ciputat Timur, Kota Tangerang Selatan berpengaruh signifikan terhadap Kepuasan Pasien. Hasil pengujian hipotesis ini sejalan dengan temuan atas baik secara simultan dan parsial Pelayanan berpengaruh signifikan 
terhadap Kepuasan Kerja (Az-zahroh, 2017; Sanah, 2017). Pentingnya layanan yang prima atas fungsi Puskesmas dalam meningkatkan kepuasan pasien tidak terlepas dari peran layanan yang meliputi kontrol infeksi, peningkatan sistem sanitasi, layanan perawatan dan medis, pencegahan penyakit dan pengembangan aspek-aspek sosial di masyarakat akan mendukung standar kehidupan seseourang agar masyarakat mempunyai peranan yang kuat untuk turut menjaga kesehatannya (Nico A. Lumenta, 2006).

\section{KESIMPULAN DAN IMPLIKASI}

Berdasarkan hasil penelitian dan pembahasan dapat disimpulkan bahwa: (1) Lingkungan Fisik dan Pelayanan secara simultan berpengaruh signifikan terhadap Kepuasan Pasien (Y); dan (2) Lingkungan Fisik tidak berpengaruh signifikan terhadap Kepuasan Pasien sementara Pelayanan berpengaruh signifikan terhadap Kepuasan Pasien di UPT Puskesmas Ciputat Timur, Kota Tangerang Selatan. UPT Puskesmas Ciputat Timur, Tangerang Selatan dapat mengoptimalkan lingkungan fisik terutama pada penerangan/cahaya dan suhu udara karena memiliki skor analisis deskriptif terendah agar dapat membantu penglihatan dan meningkatkan suhu udara dengan menambahkan pendingin udara agar udara tidak terasa panas.

\section{DAFTAR PUSTAKA}

Aritonang, J., H., K., Erdiansih, E., \& Ningsih, L. (2016). Sosialisasi Dan Pembinaan Tentang Pentingnya Kesehatan Terhadap Khususnya Kaum Ibu-Ibu dan PAUD (Pendidikan Anak Usia Dini) Di Dusun Pekan Jum'at Kecamatan Muko-Muko Bathin VII Kab.Bungo. KUKERTA: Kuliah Kerja Nyata, 1 (2).

Az-zahroh, T. N. (2017). Pengaruh Mutu Pelayanan Kesehatan Terhadap Tingkat Kepuasan Pasien Rawat Inap Di Ruang Dewasa Umum Rumah Sakit X Kabupaten Gresik. PSIKOSAINS, 12 (2), 99-111.

Effendi, F., \& Makhfudli. (2009). Keperawatan Kesehatan Komunitas: Teori dan Praktek dalam Keperawatan. (D. Nursalam, \& M. N., Eds.) Jakarta: Salemba Medika.

Finansial.com. (2019, Oktober 10). Paradigma Kesehatan Mental. (Pusat Informasi \& Humas Universitas Airlangga) Retrieved Desember 17, 2019, from http://news.unair.ac.id/2019/10/10/paradigma-kesehatan-mental/

Ghozali, I. (2017). Aplikasi Analisis Multivariate Dengan Program: IBM SPSS 23 (VIII ed.). Semarang: Badan Penerbit UNDIP.

Handoko, T. (2015). Manajemen (Edisi 2). Yogyakarta: BPFE. 
Hasibuan, M. S. (2017). Manajemen Sumber Daya Manusia. Edisi Revisi. Cetakan ke18, Jakarta: PT Bumi Aksara. (Vols. Cetakan ke-18). Jakarta: PT Bumi Aksara.

Husain, T., \& Sani, A. (2020). Kepuasan Pelanggan Toko Online Yang Dipengaruhi Kualitas Produk Dan Layanan. JITK (Jurnal Ilmu Pengetahuan dan Teknologi Komputer), 5 (2), 291296.

Keputusan Menteri Kesehatan RI. (2014). Kebijakan Dasar Pusat Kesehatan Masyarakat. Dirjen Bina Kesehatan masyarakat. Jakarta: Kementerian Kesehatan.

Kotler, Philip T., Keller, Kevin Lane. (2014). Marketing Management (15 ed.). New Jersey: Pearson Prentice Hall.

Mamik. (2010). Organisasi Dan Manajemen Pelayanan Kesehatan Dan Kebidanan (Edisi 1). Surabaya: Prins Media Publishing.

Nico A. Lumenta, d. (2006). Kenali Jenis Penyakit dan Cara Penyembuhannya: Manajemen Hidup Sehat (ISBN: 979-20-9993-x ed.). (R. L. Toruan, Ed.) Jakarta: PT Elex Media Komputindo.

Sanah, N. (2017). Pelaksanaan Fungsi Puskesmas (Pusat Kesehatan Masyarakat) Dalam Meningkatkan Kualitas Pelayanan Kesehatan. eJournal Ilmu Pemerintahan , 5 (1), 305-314.

Sedarmayanti. (2018). Manajemen Sumber Daya Manusia: Reformasi Birokrasi, dan Manajemen Pegawai Negeri Sipil. Bandung: Reflika Aditama.

Sitinjak, L. N. (2018). Pengaruh Lingkungan Kerja Terhadap Kepuasan Kerja Karyawan (Studi Pada Karyawan PT. Mitra Pinasthika Mustika Rent Tangerang Selatan). Jurnal Administrasi Bisnis (JAB) , 60 (2), 162-168.

Sugiyono. (2018). Metode Penelitian Evaluasi: Pendekatan Kuantitatif, Kualitatif, dan Kombinasi. Bandung: CV. Alfabeta.

Tjiptono, F. (2014). Pemasaran Jasa- Prinsip, Penerapan, dan Penelitian. Yogyakarta: Andi Offset. 